\title{
Incomplete degradation of lichen usnic acid and atranorin in Svalbard reindeer (Rangifer tarandus platyrhynchus)
}

\author{
Michał Hubert Wegrzyn (1) ${ }^{1}$, Paulina Wietrzyk-Petka (1) ${ }^{1}$, Agnieszka Galanty (10) ${ }^{2}$, Beata Cykowska-Marzencka (1) ${ }^{3}$ \\ \& Monica Alterskjær Sundset $\mathbb{1}^{4}$ \\ 1 Prof. Z. Czeppe Department of Polar Research and Documentation, Institute of Botany, Jagiellonian University, Kraków, Poland; \\ 2 Department of Pharmacognosy, Pharmaceutical Faculty, Medical College, Jagiellonian University, Kraków, Poland; \\ ${ }^{3}$ Laboratory of Bryology, W. Szafer Institute of Botany, Polish Academy of Sciences, Kraków, Poland; \\ ${ }^{4}$ Department of Arctic and Marine Biology, UiT-The Arctic University of Norway, Tromsø, Norway
}

\begin{abstract}
Previous studies of Eurasian tundra reindeer (Rangifer tarandus tarandus) in Norway indicate that their rumen microbiota play a key role in degrading lichen secondary metabolites. We investigated the presence of usnic acid and atranorin in faecal samples from Svalbard reindeer ( $R$. tarandus platyrhynchus). Samples were collected in Bolterdalen valley together with vegetation samples from the study site. The mesic tundra in this area was dominated by vascular plants $(59 \%$ of vegetation cover). Bryophytes (16\%) and lichens (25\%) were also present. Qualitative and quantitative analyses of usnic acid and atranorin in lichen and faeces samples were performed using high-performance liquid chromatography. Contents of atranorin averaged $12.49 \pm 0.41 \mathrm{mg} \mathrm{g}^{-1}$ in the thalli of Stereocaulon alpinum, while the average level of usnic acid was lowest in Cladonia mitis $\left(12.75 \pm 2.86 \mathrm{mg} \mathrm{g}^{-1}\right)$ and highest in Flavocetraria cucullata $\left(34.87 \pm 0.47 \mathrm{mg} \mathrm{g}^{-1}\right)$. Atranorin and usnic acid were detected in the faecal samples, averaging $0.41 \pm$ 0.53 and $0.74 \pm 1.11$ (mean \pm SD) $\mathrm{mg} \mathrm{g}^{-1}$ dry matter, respectively. The presence of lichen secondary compounds in faeces from Svalbard reindeer shows that lichens are indeed included in their diet, although probably in small amounts because of depleted pastures. Contrary to previous findings in reindeer on mainland Norway, atranorin and usnic acid are not completely degraded or absorbed in Svalbard reindeer. To elucidate the mechanisms behind detoxification of lichen secondary compounds in reindeer, more research is needed on their respective rumen microbiomes and digestive enzymes.
\end{abstract}

Keywords

Lichen secondary metabolites; ruminant; faecal samples; Spitsbergen; Arctic

\section{Contact}

Michał Hubert Węgrzyn, Prof. Z. Czeppe Department of Polar Research and Documentation, Institute of Botany, Jagiellonian University, Gronostajowa 3, 30-387 Kraków, Poland E-mail:michal.wegrzyn@uj.edu.pl

\section{Abbreviations \\ HPLC: high-performance liquid chromatography SD: standard deviation}

\section{Introduction}

Lichens are associations between fungi and algae or cyanobacteria and are hence chemically and structurally very different from vascular plants. Lichens synthesize and accumulate a large variety of secondary metabolites (Orange et al. 2001) that serve diverse functions, including defence against herbivory and microbes. Perhaps the most studied of these secondary compounds are usnic acid and atranorin (Cocchietto et al. 2002; Honda et al. 2010; White et al. 2014). Atranorin (3-hydroxy-4-methoxycarbonyl-2,5-dimethylphenyl; $\mathrm{C}_{19} \mathrm{H}_{18} \mathrm{O}_{8}$ ) is a $\beta$-orcinol derivative biosynthesized through the acetyl-polymalonyl pathway (Studzinska-Sroka et al. 2017). Usnic acid (2,6-diacetyl-7,9-dihydroxy-8,9b-dimethyl-1,3(2H,9b$\mathrm{H}$ )-dibenzo-furandione; $\mathrm{C}_{18} \mathrm{H}_{16} \mathrm{O}_{7}$ ) is a yellow pigment, which occurs in two enantiomeric forms (Ingólfsdóttir 2002). Both substances are insoluble in water. Solubility is weak in methyl and ethyl alcohol, but both compounds dissolve very well in acetone and chloroform (Stark et al. 1950; Podterob 2008). The process of usnic acid hydrolysis is not known, whereas the atranorin hydrolysis takes place after application of water acidified to $\mathrm{pH} 2$ with $\mathrm{HCl}$ and heated for one day at $60^{\circ} \mathrm{C}$ (Bourgeois et al. 1999). 
Total degradation of the usnic acid is known to occur under extreme conditions after the use of strong bases or acids and long-term heating at high temperature (Shoji 1962). Absorbing and protecting the lichen from UV radiation, atranorin and usnic acid are completely resistant to UV radiation (BeGora \& Fahlset 2000, 2001). There are no studies so far on the microbial degradation process of these substances in nature, apart from in the digestive system of ruminants (Palo 1993; Sundset et al. 2008; Barboza et al. 2010; Sundset et al. 2010; Glad et al. 2014; Sundset et al. 2015). Laboratory studies have shown that the bacteria Pseudomonas sp. (Kutney, Leman et al. 1977), the mould fungus Mucor globosus (Kutney et al. 1984) and the soil fungus Mortierella isabellina (Kutney, Baarschers et al. 1977) can take part in the decomposition of usnic acid derivatives.

Data regarding usnic acid degradation or absorption are limited, although the liver toxic effect in humans is well known. Many in vitro studies have described the mechanism of usnic acid toxicity as the uncoupling of oxidative phosphorylation in liver mitochondria (Araújo et al. 2015), but information on usnic acid pharmacokinetics in the living organism is scarce. Some experiments on rabbits indicate that mean terminal half-life of usnic acid level in plasma was $18.9 \pm 2.9$ hours after oral administration (Krishna \& Venkataramana 1992). No information exists on the in vivo metabolism of usnic acid; only some in vitro studies on human liver fraction suggest the presence of oxidized metabolites and two glucuronide conjugates after incubation (Foti et al. 2008). Recent results on human, rat and mouse microsomes in vitro indicated that usnic acid was converted into two reactive metabolites, which formed adducts with glutathione, and suggested a possible structure of the metabolites (Piska et al. 2018). Further experiments are needed to explain the metabolic fate of usnic acid in the living organism.

Both atranorin and usnic acid are known for their antiviral, antimicrobial and antiprotozoal properties and their importance in chemical ecology by demonstrating lichen-microbe, lichen-plant and lichen-animal interactions (Ingólfsdóttir 2002). Lichens are the only organisms able to synthesize usnic acid (Ingólfsdóttir 2002), while atranorin can also be found in two bryophytes, the tropical species Frullania trichodes (Ragasa et al. 2016) and the Eurasian range species Homalia trichomanoides (Wang et al. 2005), and some tropical trees (de Carvalho et al. 2000; Nasser et al. 2009). None of the above species is present in Svalbard. In the Arctic, the only known sources of both compounds are terricolous and fruticose lichens (Table 1).

Atranorin is antibacterial, but its toxicity has not been shown in animal models so far (De Melo et al. 2011), while usnic acid can be toxic to both animals and humans (Dailey et al. 2008) and even lethal in high doses, as shown for sheep (Durazo et al. 2004). Still lichens may contribute more than $50 \%$ of the winter diet of reindeer in Subarctic and Arctic areas where lichens are an abundant part of the vegetation (Borch-Iohnsen et al. 1996; Svihus \& Holand 2000; Storeheier et al. 2002; Denryter et al. 2017). It is not fully understood how reindeer cope with such high intakes of lichen secondary compounds. There may be several answers to this, but studies so far have indicated that usnic acid and other phenolic secondary compounds are detoxified through microbial degradation in the rumen (Sundset et al. 2009). In addition, endogenous enzymes in the intestine and/or the liver of the animal may also contribute to detoxification. However, if not degraded or only partly degraded, and not absorbed, the secondary compounds will appear in the faeces. In general, lichens are low in proteins but contain large amounts of polysaccharides and are easily digested by reindeer, as long as the rumen microflora has had time to adapt to the substrate (Storeheier et al. 2002). The bacterial and archaeal profiles in the rumen and cecum of Eurasian tundra reindeer (Rangifer tarandus tarandus) in Norway change significantly in response to a pure lichen diet compared to a concentrate reindeer feed (Salgado-Flores et al. 2016). The ability of reindeer to utilize lichens as a source of energy and nutrients indicates that the rumen microflora must have adapted both resistance to and even enzymes to degrade usnic acid and other secondary phenolic compounds in the lichens (Sundset et al. 2015). This hypothesis is supported by studies indicating that the rumen microbiota in reindeer play a key role in detoxifying usnic acid (Palo 1993; Sundset et al. 2008; Sundset et al. 2010; Glad et al. 2014). Furthermore, Sundset et al. (2010) demonstrated the complete degradation of usnic acid in the rumen of lichen-fed reindeer in Norway, documenting a very efficient rumen microbial degradation of this lichen

Table 1 Macrolichens in the study area showing presence (+) of the secondary metabolites (atranorin and usnic acid) (Olech et al. 2011; Węgrzyn et al. 2013; Węgrzyn et al. 2016; Ziaja et al. 2016).

\begin{tabular}{lcc}
\hline Species of macrolichens & Atranorin & Usnic acid \\
\hline Cladonia amaurocraea (Flörke) Schaer. & + \\
Cladonia gracilis (L.) Willd. & + & + \\
Cladonia macroceras (Delise) Hav. & + & + \\
Cladonia mitis Sandst. & & + \\
Cladonia pleurota (Flörke) Schaer. & + \\
Cladonia rangiferina (L.) Weber ex Wigg. & + \\
Cladonia uncialis (L.) Wigg. & + \\
Flavocetraria cucullata (Bellardi) & + \\
Kärnefelt \& Thell & + \\
Flavocetraria nivalis (L.) Kärnefelt \& Thell & + \\
Stereocaulon alpinum Laur. & + \\
\hline
\end{tabular}


secondary compound in these animals, with no usnic acid appearing in their liver or faeces.

Despite their ingestion, lichens are not essential to the survival of reindeer as not all populations of reindeer have access to lichens as part of their natural diet. On the Svalbard tundra, the presence of fruticose lichens has decreased with the increase in the number of reindeer (Wegener et al. 1992; Wegener \& Odasz-Albrigtsen 1998). Comparative studies of the conservation of tundra plant communities in Sørkapp Land and Kaffiøyra, both on the island of Spitsbergen, showed that Svalbard reindeer eat mainly Flavocetraria nivalis, F. cucullata and Cladonia mitis. Svalbard reindeer do not feed on Cetrariella delisei, which means that its contribution in tundra plant communities in Svalbard increases significantly (Węgrzyn et al. 2013; Węgrzyn \& Wietrzyk 2015; Ziaja et al. 2016; Węgrzyn et al. 2016).

The Svalbard reindeer ( $R$. tarandus platyrhynchus) is the most northerly herbivorous mammal in the world. They have been isolated and resident at the archipelago of Svalbard $\left(74-81^{\circ} \mathrm{N}\right)$ for thousands of years (Van der Knaap 1986; Tyler 1986; Reimers 2012) and are adapted to austere nutritional conditions (Hakala et al. 1986; Tyler 1986; Solberg et al. 2001; Bjørkvoll et al. 2009; Hansen et al. 2010). During the short Arctic summer, Svalbard reindeer feed on a lush tundra vegetation of vascular plants, including grasses, herbs, sedges and deciduous shrubs in the lowland plains and valleys, to accumulate fat for the winter (Reimers 1982; Tyler 1986; Staaland et al. 1993; Henriksen et al. 1997; Sørmo et al. 1999; Lindner 2003; Bjørkvoll et al. 2009). These body reserves are usually exhausted in early winter and for the rest of the winter the reindeer rely on pastures along mountain slopes, plateaus and ridges where less snow accumulates (Tyler 1986; Bjørkvoll et al. 2009). The winter diet consists of bryophytes and fibrous vascular plants (Sørmo et al. 1999; Bjørkvoll et al. 2009). Optimal utilization of these poor-quality, fibrous forages is crucial for survival through the long, cold winter. Svalbard reindeer have adapted a unique rumen microbiome that is unusually effective in degrading cellulose and plant biomass (Orpin et al. 1985; Sundset et al. 2007; Sundset et al. 2009; Pope et al. 2012).

The aim of this study was to investigate whether Svalbard reindeer are capable of degrading lichen secondary compounds such as usnic acid and atranorin. Do Svalbard reindeer seek and eat terricolous and fruticose lichensthe only sources of these two substances in Svalbarddespite their low coverage, and are they able to degrade these lichen secondary compounds-or do they appear in their faeces?

This research was carried out in three stages: (1) the quantitative proportion of fruticose lichens in the tundra ecosystem grazed by reindeer in the Borteldalen valley in
Svalbard was determined by using phytosociological methods (Braun-Blanquet 1964); (2) fruticose lichens occurring in the research area were collected and analysed to determine their concentration of atranorin and usnic acid; and (3) reindeer faeces samples occurring in the research area on the transect were collected and analysed to determine their concentration of atranorin and usnic acid.

Our hypothesis is that the relatively low abundance of lichens in Svalbard has reduced the capacity of Svalbard reindeer to metabolize atranorin and usnic acid compared to populations with access to abundant lichens in their environments. Therefore, we will detect atranorin and usnic acid in the faeces of reindeer in our study.

\section{Material and methods}

\section{Fieldwork}

The fieldwork was conducted in Bolterdalen in July and

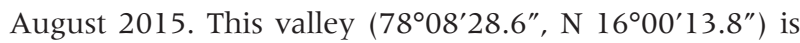
located in central Spitsbergen about $10 \mathrm{~km}$ east of Longyearbyen. Twenty-eight sampling sites were designated along the transect running through the valley (Fig. 1). The sample sites were located on the eastern hillside at heights ranging between 150 and $250 \mathrm{~m}$ a.s.l. At each sampling site $(10 \mathrm{~m} \times 10 \mathrm{~m})$, all reindeer faecal material was collected and divided into three separate samples for chemical analyses. Along the transect, in the selected sites of faeces collection, $1 \mathrm{~m}^{2}$ plots were designated to map the vegetation of the study area. Plot sites were selected in accordance with the phytosociological methodology (Braun-Blanquet 1964), with the objective of capturing the species diversity of the habitat. Within plots, the species of vascular plants, bryophytes and lichens and their percentage cover were obtained. Ten plots were analysed. Vegetation data were calculated according to the Braun-Blanquet scale (BraunBlanquet 1964). Fruticose lichens were collected from the plots to determine usnic acid and atranorin contents in the lichen thallus. The small amounts of lichens in the study area (which were heavily grazed by reindeer) made it difficult to collect all studied lichen species in all sampling sites. Altogether, seven samples of the fruticose lichen were collected: three individual samples of $C$. mitis, one sample of F. cucullata, one sample of $F$. nivalis (containing usnic acid) and three samples of Stereocaulon alpinum (containing atranorin). The lichen specimens of each species were divided into three separate samples for chemical analyses. All samples were air-dried and packed in sealed plastic bags.

\section{Chemical analyses}

The quantity of atranorin and usnic acid in the faecal and lichen samples was examined according to the method 


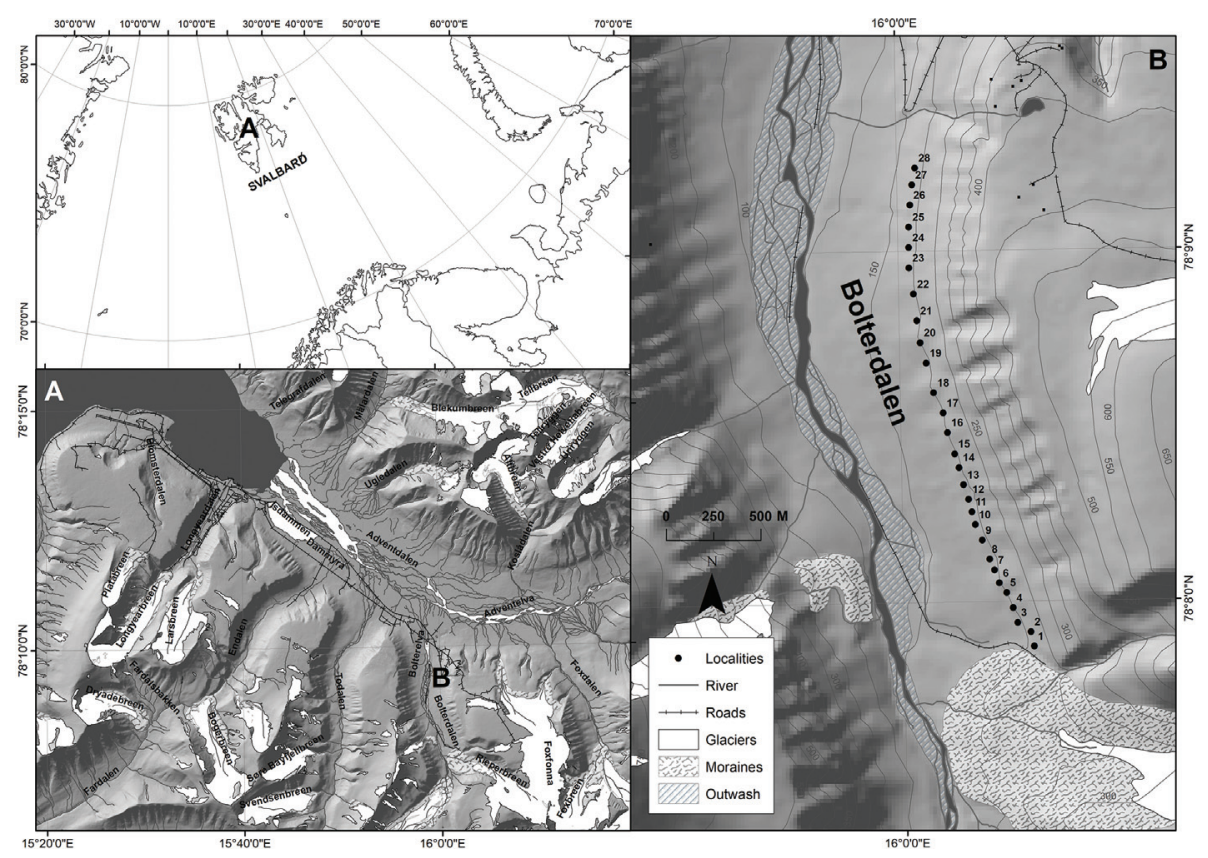

Fig. 1 Map of study area showng the location of Adventdalen (A) and Bolterdalen (B) (๔ Norwegian Polar Institute 2016).

described by Manojlović et al. (2010), with a minor modification. The modification to the method was that the mobile phase proportion was changed from 80:20 to $85: 15$, which gave better peak separation in the chromatograms. The analysis was performed by using a Dionex high-performance liquid chromatography (HPLC) system with a C- 18 column $(5 \mu \mathrm{m}, 250 \mathrm{~mm} \times 4.6 \mathrm{~mm})$ and a C- 18 precolumn $(5 \mu \mathrm{m}, 10 \mathrm{~mm} \times 4 \mathrm{~mm})$ at $25^{\circ} \mathrm{C}$. The mobile phase featured water with $1 \% 0.1 \mathrm{~N} \mathrm{H}_{3} \mathrm{PO}_{4}(\mathrm{v} / \mathrm{v})(\mathrm{A})$ and methanol (B), A:B 15:85. The sample injection volume was $20 \mu \mathrm{l}$ and the flow rate was $1.0 \mathrm{ml} / \mathrm{min}$. The task was performed with a photodiode array detector set at $250 \mathrm{~nm}$.

To prepare stock standard solutions for the calibration curve, $5 \mathrm{mg}$ of standard atranorin (Chromadex) and (+)usnic acid (Sigma-Aldrich) was dissolved in $5 \mathrm{ml}$ chloroform. The appropriate volumes were transferred to volumetric flasks and diluted with the same solvent to give working standard solutions of the concentrations: $1,0.5,0.25,0.125$ and $0.0625 \mathrm{mg} \mathrm{m}^{-1}$. Each concentration was analysed in triplicate in the conditions described above to obtain a calibration curve.

Samples of the reindeer faeces and lichen material, previously dried at room temperature for seven days, were ground in a mortar. From each sample, an amount of $100 \mathrm{mg}$ was used for extraction with HPLC grade chloroform $(10 \mathrm{ml})$ in a water bath $\left(90^{\circ} \mathrm{C}\right)$ under reflux for one hour. The extracts were transferred to a $10-\mathrm{ml}$ volumetric flask. Volumes of $1.5 \mathrm{ml}$ were filtered through a 0.45 - $\mu \mathrm{m}$ micropore membrane into HPLC vials for analysis. Atranorin and usnic acid were identified by comparing retention times with that of the reference compounds and the amounts were quantified by integrating peak area with the reference to the standard curve.

\section{Statistical analyses}

The Braun-Blanquet method (Braun-Blanquet 1964) was used to characterize vegetation in the Bolterdalen valley. This method involves making a series of $1-\mathrm{m}^{2}$ phytosociological plots (divided into 100 squares, each $10 \mathrm{~cm} \times 10 \mathrm{~cm}$ ), within which the species numbers and percentage cover of species of vascular plants, bryophytes and lichens are obtained. One square corresponds to $1 \%$ cover of each taxon (Table 2). The synthetic table of vegetation in Bolterdalen valley was created based on data from plots. For each species the stability value was determined, which is the ratio within which species were present in all plots. It was calculated to specify the percentage of sampling sites in which the species were recorded.

\section{Results}

\section{Study area vegetation}

Table 2 shows the list of recorded species with the degree of coverage and stability of each taxon. Vegetation was represented by mesic tundra dominated by vascular plants (59\% of vegetation cover), mainly dwarf shrubs such as Dryas octopetala, Cassiope tetragona and Salix polaris. Bryophytes $(16 \%$ of vegetation cover) and lichens $(25 \%$ of 
Table 2 Synthetic table of vegetation showing the species coverage according to the Braun-Blanquet scale: $r$ is $0.1 \%$; + is $0.5 \%$; 1 is $<5 \%$; 2 is $5-25 \%$; 3 is 25-50\%; 4 is 50-75\%; 5 is 75-100\% and stability of each taxon (percentage of sampling sites in which species were recorded): I is 0-20\%; II is $20-40 \%$; III is 40-60\%; IV is 60-80\%; V is $80-100 \%$ (Braun-Blanquet 1964). For lichens, the morphological form of thallus is indicated: C is crustose, Fr is fruticose, Fo is foliose and $\mathrm{S}$ is squamulose.

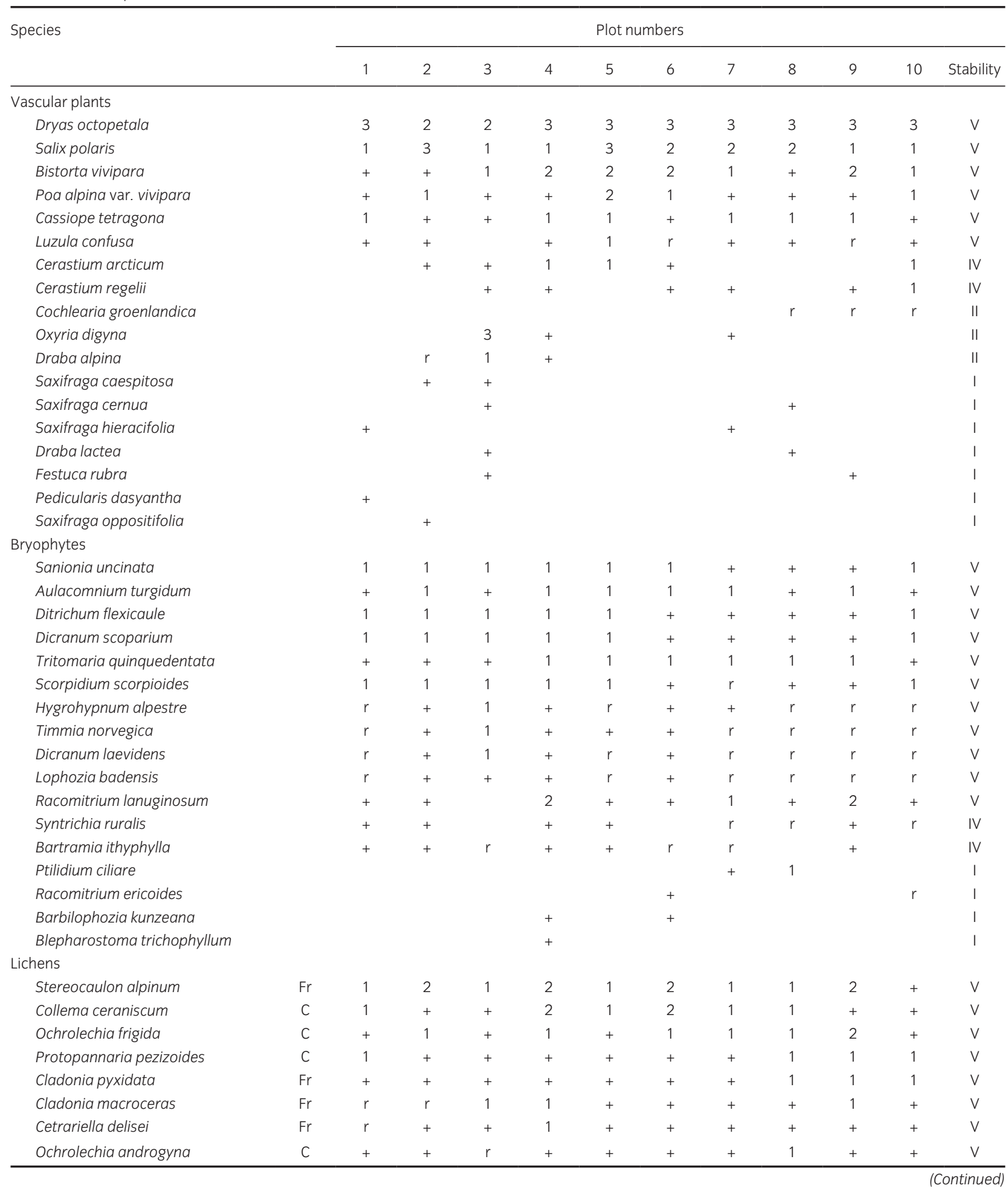


Table 2 (Continued)

\begin{tabular}{|c|c|c|c|c|c|c|c|c|c|c|c|c|}
\hline \multirow[t]{2}{*}{ Species } & \multicolumn{12}{|c|}{ Plot numbers } \\
\hline & & 1 & 2 & 3 & 4 & 5 & 6 & 7 & 8 & 9 & 10 & Stability \\
\hline Peltigera venosa & Fo & 3 & 1 & 2 & & + & + & & + & + & + & IV \\
\hline Peltigera didactyla & Fo & & 2 & & + & + & + & 1 & 1 & 1 & + & IV \\
\hline Cladonia mitis & $\mathrm{Fr}$ & & + & + & & & + & & + & + & & III \\
\hline Psoroma hypnorum & C & + & & & + & + & r & & & & + & III \\
\hline Peltigera leucophlebia & Fo & & & & & + & & & + & & 1 & $\|$ \\
\hline Cladonia coccifera & $\mathrm{S} / \mathrm{Fr}$ & & & & $r$ & + & & & & & + & $\|$ \\
\hline Flavocetraria cucullata & Fo & & & + & & & & & + & + & & $\|$ \\
\hline Flavocetraria nivalis & Fo & & + & & & & & & & + & & 1 \\
\hline Caloplaca tiroliensis & C & r & & & & & & & & & r & I \\
\hline Caloplaca ammiospila & C & r & & & & & & & & & r & 1 \\
\hline Solorina crocea & Fo & & r & & & & r & & & & & । \\
\hline Lecidea ementiens & C & r & & & & & & & & & + & । \\
\hline Arthrorhaphis alpina & C & + & & & & & & & & & & I \\
\hline Polyblastia shaereriana & C & & & & + & & & & & & & । \\
\hline Rinodina turfacea & C & r & & & & & & & & & & । \\
\hline
\end{tabular}

vegetation cover) comprised less of the vegetation cover than vascular plants (Table 2).

Among the lichens, the crustose and foliose species were dominant. Foliose species such as Peltigera venosa and crustose species such as Collema ceraniscum and Ochrolechia frigida were the main components of biological soil crusts. Fruticose lichens, for example, F. nivalis, F. cucullata and C. mitis, occurred rarely. S. alpinum, C. delisei and C. macroceras were the only fruticose species present in all plots (Table 2). Of the above-mentioned species, S. alpinum had the highest percentage cover.

\section{Determination of usnic acid and atranorin contents in lichens}

Four lichen species were studied for secondary compounds (Table 3). Stereocaulon alpinum was chosen as the main source of atranorin because of its relatively high occurrence in the study area (Table 2). The mean content of atranorin in thalli of S. alpinum was $12.49 \mathrm{mg} \mathrm{g}^{-1}$ (Table 3). Of the three lichen species containing usnic acid, the highest mean content (34.87 $\mathrm{mg} \mathrm{g}^{-1}$ ) was detected in F. cucullata (Table 3), an intermediate content was detected in F. nivalis (24.23 $\mathrm{mg} \mathrm{g}^{-1}$ ) and the lowest content was found in the thalli of C. mitis (12.75 $\mathrm{mg} \mathrm{g}^{-1}$; Table 3).

\section{Detection of usnic acid and atranorin in reindeer faeces}

Both lichen secondary metabolites, usnic acid and atranorin, were detected in the majority of the reindeer faeces samples collected (Table 4). Atranorin was detected
Table 3 Average content of usnic acid and atranorin $\left(\mathrm{mg} \mathrm{g}^{-1}\right)$, with SD, in lichen samples collected in the study area.

\begin{tabular}{lccc}
\hline Species & $n$ & Average & SD \\
\hline Usnic acid & & & \\
Cladonia mitis & 9 & 12.75 & 2.86 \\
Flavocetraria cucullata & 3 & 34.87 & 0.47 \\
Flavocetraria nivalis & 3 & 24.23 & 0.85 \\
Atranorin & & & \\
Stereocaulon alpinum & 9 & 12.49 & 0.405 \\
\hline
\end{tabular}

in $21(75 \%)$ of the samples $(n=28)$, while usnic acid was detected in 19 samples $(68 \%)$. Five samples contained neither atranorin nor usnic acid (Table 4). In addition to these latter samples, atranorin was absent from a further five samples and usnic acid was absent from a further two samples. Atranorin content varied between 0.05 and $1.81 \mathrm{mg} \mathrm{g}^{-1}$, and usnic acid varied between 0.04 and $4.17 \mathrm{mg} \mathrm{g}^{-1}$. The mean content of usnic acid $\left(0.74 \mathrm{mg} \mathrm{g}^{-1}\right)$ calculated for 28 samples was almost double that of the mean atranorin levels $\left(0.41 \mathrm{mg} \mathrm{g}^{-1}\right)$.

\section{Discussion}

This study demonstrates that both usnic acid and atranorin are excreted in the faeces of free-ranging Svalbard reindeer (Table 4). This is consistent with our hypothesis that the studied lichen substances are not completely degraded in the digestive tract of Svalbard reindeer. Previous studies of usnic acid digestion conducted on Eurasian tundra reindeer in Norway in controlled feeding 
Table 4 The average content of usnic acid and atranorin $\left(\mathrm{mg} \mathrm{g}^{-1}\right)$, with SD, in reindeer faeces at different sampling sites (see Fig. 1).

\begin{tabular}{|c|c|c|c|c|c|}
\hline \multirow{2}{*}{$\begin{array}{l}\text { Sampling } \\
\text { sites }\end{array}$} & \multirow[t]{2}{*}{$N$} & \multicolumn{2}{|c|}{ Atranorin } & \multicolumn{2}{|c|}{ Usnic acid } \\
\hline & & Average & SD & Average & SD \\
\hline$\overline{1}$ & 3 & 1.8 & 0.014 & 0.112 & 0.008 \\
\hline 2 & 3 & 1.22 & 0.049 & 0.337 & 0.02 \\
\hline 3 & 3 & 1.22 & 0.062 & 0.225 & 0.027 \\
\hline 4 & 3 & 0.335 & 0.015 & 1.25 & 0.078 \\
\hline 5 & 3 & 0 & 0 & 0.3 & 0.046 \\
\hline 6 & 3 & 0.065 & 0.007 & 1.15 & 0.074 \\
\hline 7 & 3 & 0.55 & 0.019 & 0 & 0 \\
\hline 8 & 3 & 0.157 & 0.022 & 3.8 & 0.158 \\
\hline 9 & 3 & 0.08 & 0.007 & 1.52 & 0.391 \\
\hline 10 & 3 & 0 & 0 & 4.02 & 0.211 \\
\hline 11 & 3 & 1.07 & 0.05 & 2.25 & 0.205 \\
\hline 12 & 3 & 0.07 & 0.009 & 0.08 & 0.01 \\
\hline 13 & 3 & 0.685 & 0 & 1.46 & 0.072 \\
\hline 14 & 3 & 1.05 & 0.017 & 0.077 & 0 \\
\hline 15 & 3 & 0 & 0 & 0.063 & 0.02 \\
\hline 16 & 3 & 0.245 & 0.008 & 1.28 & 0.085 \\
\hline 17 & 3 & 1.58 & 0.02 & 0.109 & 0.022 \\
\hline 18 & 3 & 0.334 & 0.01 & 0.353 & 0.039 \\
\hline 19 & 3 & 0.116 & 0.005 & 0.09 & 0.01 \\
\hline 20 & 3 & 0 & 0 & 0 & 0 \\
\hline 21 & 3 & 0 & 0 & 0 & 0 \\
\hline 22 & 3 & 0 & 0 & 0 & 0 \\
\hline 23 & 3 & 0 & 0 & 0 & 0 \\
\hline 24 & 3 & 0 & 0 & 0 & 0 \\
\hline 25 & 3 & 0.067 & 0.015 & 1.98 & 0.266 \\
\hline 26 & 3 & 0 & 0 & 0.057 & 0.015 \\
\hline 27 & 3 & 0.545 & 0.014 & 0.073 & 0.015 \\
\hline 28 & 3 & 0.269 & 0.026 & 0 & 0 \\
\hline
\end{tabular}

experiments, in which the animals were fed a pure lichen diet, showed that usnic acid was completely degraded in the rumen, while perlatolic acid was still appearing in their faeces (Sundset et al. 2010). Joo et al. (2014) created a length-heterogeneity database based on potential food sources and faecal samples from free-ranging Svalbard reindeer on summer pasture to investigate their forage preferences. Using length-heterogeneity polymerase chain reaction on faecal samples, they found that lichens (Stereocaulon sp. and Ochrolechia sp.) contributed to 20\% of the "peak area" in 2012 and 7\% in the 2011 samples, while plants such as Salix polaris and Saxifraga oppositifolia contributed the most. The incomplete degradation of atranorin and usnic acid by Svalbard reindeer shown here demonstrates that Svalbard reindeer are indeed eating lichens, which contain these secondary metabolites, although their intake must be low on account of the scarcity of lichens on their feeding grounds. This is confirmed by our phytosociological survey (Table 2), which shows that lichens were only a small part of plant communities, most likely because of the heavy grazing pressure in the area by reindeer (Wegener et al. 1992; Wegener \& Odasz-Albrigtsen 1998; Węgrzyn et al. 2013; Węgrzyn et al. 2016). The results obtained for the pasture coverage of fruticose lichens containing usnic acid and atranorine in tundra communities give incomplete knowledge about the actual amount of lichen consumed by the reindeer. Information on the biomass intake of each plant would be better; however, in the field conditions, when examining free-living animals, the biomass parameter of each of the fractions (lichens, bryophytes and vascular plants) remains to be determined. While data on rumen contents (Bjørkvoll et al. 2009) may offer some insights, it must be noted that these results do not allow a reasonable estimation of biomass intake of plant fractions as plant degradation is not uniform across species.

Our study (Table 3) furthermore demonstrates that usnic acid (24.23 $\mathrm{mg} \mathrm{g}^{-1}$ ) concentration in F. nivalis sampled in the study area is lower than those reported from Kongsfjorden in north-western Spitsbergen. Bjerke et al. (2004) found the average content of usnic acid in the F. nivalis thallus, where it was $60.3 \mathrm{mg} \mathrm{g}^{-1}$. Comparing different areas, Bjerke et al. (2005) also found somewhat variable usnic acid concentrations: $53 \mathrm{mg} \mathrm{g}^{-1}$ in Kangerlussuaq (western Greenland), $52.8 \mathrm{mg} \mathrm{g}^{-1}$ in Tromsø (northern Norway), $52.4 \mathrm{mg} \mathrm{g}^{-1}$ in Punta Arenas (southern Chile) and $51.1 \mathrm{mg} \mathrm{g}^{-1}$ in Ny-Alesund (Svalbard). These results are also high in relation to our results from Bolterdalen, Svalbard. The variability in the concentration of usnic acid in the thallus is correlated with climatic factors (Bjerke 2004), with the coldest regions having the highest levels. Additional, positive correlations with altitude were found in one lichen study (Bjerke et al. 2004), but these were probably related to lower temperatures at higher altitudes. Such an explanation of the differences in the content of usnic acid in other studies agrees with the amounts that have been obtained in the thalli from the Bolterdalen valley, which is located in the warmest region of Spitsbergen.

The lichen diet used in the Sundset et al. study (2010) was dominated by C. stellaris and contained $9.1 \mathrm{mg} \mathrm{g}^{-1}$ in dry matter. The usnic acid values obtained for $C$. mitis, F. nivalis and F. cucullata in the current study are much higher (Table 3). The concentration of atranorin in Stereocaulon sp. from boreal woodland and tundra in Alaska (Falk et al. 2008) was only around $4.84 \mathrm{mg} \mathrm{g}^{-1}$, which is much lower compared to our Svalbard samples. It is striking that secondary metabolites were recorded in the faeces of our Svalbard reindeer despite the low coverage of lichens in the tundra.

We hypothesize that the low lichen input in Svalbard reindeer creates low exposure of the rumen microflora to these antibiotic secondary compounds, which means less evolutionary pressure for the microbiome to adapt coping 
mechanisms such as resistance and utilization and detoxification of these dietary antinutrients. This may result in reduced degradation of secondary metabolites by the gut microbes (or endogenous enzymes, if present) and might explain the excretion of undigested or absorbed secondary compounds with the faeces. This mechanism would also account for the lack of secondary metabolites in the faeces of reindeer in mainland Norway fed with a pure lichen diet in the Sundset et al. study (2010).

The absence of atranorin and/or usnic acid in some of the samples (Table 4) may be due to several factors, including lichen avoidance by reindeer and different stages of usnic acid degradation in the rumen of certain reindeer connected with different accessibility to lichen secondary compounds by microbial community or seasonal changes in diet selection. The faecal samples were not collected fresh straight after defecation. However, secondary lichen compounds are only dissolved in aromatic solvents like acetone, toluene and benzene. Rain and snow have not dissolved or washed out these metabolites from the faecal material and have not lowered their concentration in our samples.

Storeheier et al. (2002) reported the medium range of digestibility of different lichen species in ruminal inoculum in vitro to be between 41 and $78 \%$, while Sundset et al. (2010) reported the digestibility of lichens eaten by reindeer to amount to approximately $74 \%$. This indicates that the total digestion of lichens may also influence the digestibility of secondary metabolites inside the lichen thalli. This may be associated with the accessibility of lichen secondary compounds deposited in lichen thalli to degradation by rumen microbiota. In the study conducted by Sundset et al. (2010), a diet of mainly C. stellaris was used to feed the reindeer. This lichen species does not have a typical cortex layer and usnic acid is deposited outside loose medullary fungal hyphae (Smith et al. 2009). The access to the usnic acid for the rumen microbes may consequently be quicker with $C$. stellaris compared to species from the Flavocetraria genus, in which usnic acid is mainly deposited in a cortex composed of dense conglutinated hyphae (Kärnefelt et al. 1994; Węgrzyn et al. 2013), which might make it less digestible. Previous studies have shown that the rumen microbiome of the Svalbard reindeer is unique and different from that of the Norwegian reindeer (Orpin et al. 1985; Sundset et al. 2007; Pope et al. 2012). The geographical isolation of Svalbard's reindeer population might explain the loss of symbiotic rumen microorganisms and the reason for not allowing full degradation of usnic acid as observed in the mainland reindeer population. Our results indicate differences in secondary compound degradation between Norwegian (Sundset et al. 2010) and Svalbard reindeer. Finding the explanation to this phenomenon requires further research into their respective microbiomes and digestive enzymes.

\section{Acknowledgements}

The authors would like to thank Dr Gabriela Wagner for her kind help in polishing and improving the language of the manuscript prior to publishing. They would also like to express their gratitude to a number of anonymous reviewers for their suggestions and remarks on the manuscript.

\section{Disclosure statement}

No potential conflict of interest was reported by the authors.

\section{Funding}

The authors are grateful to their private sponsors for enabling them to organise their expedition to Spitsbergen. They also received financial support from the statutory fund of the Institute of Botany of the Jagiellonian University (DS/MND/WBiNoZ/23/2015). The work of BCM was supported by the statutory fund of the W. Szafer Institute of Botany of the Polish Academy of Sciences.

\section{References}

Araújo A.A.S., de Melo M.G.D., Rabelo T.K., Nunes P.S., Santos S.L., Serafini M.R., Santos M.R.V., Quintans-Júnior L.J. \& Gelain D.P. 2015. Review of the biological properties and toxicity of usnic acid. Natural Product Research 29, 2167-2180, https://doi.org/10.1080/14786419.2015.1007455.

Barboza P.S., Bennet A., Lignot J.-H., Macie R.I., McWhorter T.J., Secor S.M., Skovgaard N., Sundset M.A. \& Wang T. 2010. Digestive challenges for vertebrate animals: microbial diversity, cardiorespiratory coupling, and dietary specialization. Physiological and Biochemical Zoology 83, 764-774, https://doi.org/10.1086/650472.

BeGora M.D. \& Fahlset D. 2000. An alternative method for quantification of lichen secondary products. The Bryologist 103, 563-567, https://doi.org/10.1639/0007-2745(2000) 1 03[0563:AAMFTQ]2.0.CO;2.

BeGora M.D. \& Fahlset D. 2001. Usnic acid and atranorin concentrations in lichens in relation to bands of UV irradiance. The Bryologist 104, 134-140, https://doi.org/10.1639/00072745(2001) 104[0134:UAAACI]2.0.CO;2.

Bjerke J.W., Elvebakk A., Domínguez E. \& Dahlback A. 2005. Seasonal trends in usnic acid concentrations of Arctic, alpine and Patagonian populations of the lichen Flavocetraria nivalis. Phytochemistry 66, 337-344, https://doi. org/10.1016/j.phytochem.2004.12.007.

Bjerke J.W., Joly D., Nilsen L. \& Brossard T. 2004. Spatial trends in usnic acid concentrations of the lichen Flavocetraria nivalis along local climatic gradients in the Arctic (Kongsfjorden, Svalbard). Polar Biology 27, 409-417, https://doi.org/10.1007/s00300-004-0590-8.

Bjørkvoll E., Pedersen B., Hytteborn H., Jónsdóttir I.S. \& Langvatn R. 2009. Seasonal and interannual dietary variation during winter in female 
Svalbard reindeer (Rangifer tarandus platyrhynchus). Arctic, Antarctic, and Alpine Research 41, 88-96, https://doi. org/10.1657/1523-0430-41.1.88.

Borch-Iohnsen B., Nilssen K.J. \& Norheim G. 1996. Influence of season and diet on liver and kidney content of essential elements and heavy metals in Svalbard reindeer. Biological Trace Element Research 51, 235-247, https://doi. org/10.1007/BF02784078

Bourgeois G., Suire C., Vivas N. \& Vitry C. 1999. Atraric acid, a marker for epiphytic lichens in the wood used in cooperage: identification and quantification by GC/MS/(MS). Analusis 27, 281-283, https://doi.org/10.1051/analusis:1999100.

Braun-Blanquet J. 1964. Pflanzensoziologie. Grundzüge der Vegetationskunde. (Plant sociology. Basics of vegetation science.) Vienna: Springer.

Cocchietto M., Skert N., Nimis P. \& Sava G. 2002. A review on usnic acid, an interesting natural compound. Naturwissenschaften 89, 137-146, https://doi.org/10.1007/ s00114-002-0305-3.

Dailey R.N., Montgomery D.L., Ingram J.T., Siemion R., Vasquez M. \& Raisbeck M.F. 2008. Toxicity of the lichen secondary metabolite (+)-usnic acid in domestic sheep. Veterinary Pathology 45, 19-25, https://doi.org/10.1354/ vp.45-1-19.

de Carvalho M.G., de Carvalho G.J. \& Braz-Filho R. 2000. Chemical constituents from Ouratea floribunda: complete ${ }^{1} \mathrm{H}$ and ${ }^{13} \mathrm{C}$ NMR assignments of atranorin and its new acetyl derivative. Journal of the Brazilian Chemical Society 11, 143-147, https://doi.org/10.1590/S0103-50532000000200007.

de Melo M.G.D., de Souza Araújo A.A., Serafini M.R., Carvalho L.F., Bexerra M.S., Ramos C.S., Bonjardim L.R., Albuquerque-Jùnior R.L.C., Lima J.T., Siqueira R.S., Fortes V.S., Fonseca M.J.V. \& Quintans-Júnior L.J. 2011. Anti-inflammatory and toxicity studies of atranorin extracted from Cladina kalbii Ahti in rodents. Brazilian Journal of Pharmaceutical Sciences 47, 861-872, https://doi. org/10.1590/S1984-82502011000400024.

Denryter K.A., Cook R.C., Cook J.G. \& Parker K.L. 2017. Straight from the caribou's (Rangifer tarandus) mouth: detailed observations of tame caribou reveal new insights into summer-autumn diets. Canadian Journal of Zoology 95 , 81-94, https://doi.org/10.1139/cjz-2016-0114.

Durazo F.A., Lassman C., Han S.H., Saab S., Lee N.P., Kawano M., Saggi B., Gordon S., Farmer D.G., Yersiz H., Goldstein R.L.I., Ghobrial M. \& Busuttil R.W. 2004. Fulminant liver failure due to usnic acid for weight loss. The American Journal of Gastroenterology 99, 950-952, https://doi. org/10.1111/j.1572-0241.2004.04165.x.

Falk A., Green T.K. \& Barboza P. 2008. Quantitative determination of secondary metabolites in Cladina stellaris and other lichens by micellar electrokinetic chromatography. Journal of Chromatography A 1182, 141-144, https://doi. org/10.1016/j.chroma.2007.12.035.

Foti R.S., Dickmann L.J., Davis J.A., Greene R.J., Hill J.J., Howard M.L., Pearson J.T., Rock D.A., Tay J.C., Wahlstrom J.L. \& Slatter J.G. 2008. Metabolism and related human risk factors for hepatic damage by usnic acid containing nutritional supplements. Xenobiotica 38, 264-280, https:// doi.org/10.1080/00498250701802514.
Glad T., Barboza P., Mackie R.I., Wright A.D.G., Brusetti L., Mathiesen S.D. \& Sundset M.A. 2014. Dietary supplementation of usnic acid, an antimicrobial compound in lichens, does not affect rumen bacterial diversity or density in reindeer. Current Microbiology 68, 724-728, https:// doi.org/10.1007/s00284-014-0534-7.

Hakala A.V.K., Staaland H., Pulliainen E. \& Røed K.H. 1986. Taxonomy and history of Arctic island reindeer with special reference to Svalbard reindeer-a preliminary report. Rangifer, Special Issue 1, 360, https://doi.org/https://doi. org/10.7557/2.6.2.676.

Hansen B.B., Aanes R. \& Sæther B.-E. 2010. Partial seasonal migration in High-Arctic Svalbard reindeer (Rangifer tarandus platyrhynchus). Canadian Journal of Zoology 88, 1202-1209, https://doi.org/10.1139/Z10-086.

Henriksen S., Aanes R., Sæther B. \& Ringsby T.H. 1997. Does availability of resources influence grazing strategies in female Svalbard reindeer? Rangifer 23, 25-37, http://dx. doi.org/10.7557/2.23.1.311.

Honda N.K., Pavan F.R., Coelho R.G., de Andrade Leite S.R., Micheletti A.C., Lopes T.I.B., Misutsu M.Y., Beatriz A., Brum R.L. \& Leite C.Q.F. 2010. Antimycobacterial activity of lichen substances. Phytomedicine 17, 328-332, https:// doi.org/10.1016/j.phymed.2009.07.018.

Ingólfsdóttir K. 2002. Usnic acid. Phytochemistry 61, 729-736, https://doi.org/10.1016/S0031-9422(02)00383-7.

Joo S., Han D., Lee E.J. \& Park S. 2014. Use of length heterogeneity polymerase chain reaction (LH-PCR) as noninvasive apporach for dietary analysis of Svalbard reindeer, Rangifer tarandus tarandus. PLoS One 9, e91552, https://doi. org/10.1371/journal.pone.0091552.

Kärnefelt I., Thell A., Randlane T. \& Saag A. 1994. The genus Flavocetraria Kärnefelt \& Thell (Parmeliaceae, Ascomycotina) and its affinities. Acta Botanica Fennica 150, 79-86.

Krishna D.R. \& Venkataramana D. 1992. Pharmacokinetics of $\mathrm{d}(+)$-usnic acid in rabbits after intravenous and oral administration. Drug Metabolism and Disposition 20, 909911, https://doi.org/10.1007/BF03188791.

Kutney J.P., Baarschers W.H., Chin O., Ebizuka Y., Hurley L., Leman J.D., Salisbury P.J., Sanchez I.H., Yee T. \& Bandoni R.J. 1977a. Studies in the usnic acid series. VIII. The biodegradation of $(+)$-usnic acid by Mortierella isabellina. Canadian Journal of Chemistry 55, 2930-2940, https://doi. org/0.1139/v77-406.

Kutney J.P., Leman J.D., Salisbury P.J., Sanchez I.H., Yee T. \& Bandoni R.J. 1977b. Studies in the usnic acid series. VII. The biodegradation of (+)-usnic acid by a Pseudomonas species. Isolation, structure determination, and synthesis of (+)-6-desacetylusnic acid. Canadian Journal of Chemistry 55, 2336-2352, https://doi.org/10.1139/v77-321.

Kutney J.P., Leman J.D., Salisbury P.J., Yee T. \& Sanchez I.H. 1984. Studies in the usnic acid series. IX. The biodegradation of (+)-usnic acid by Mucor globosus. Canadian Journal of Chemistry 62, 320-325, https://doi.org/10.1139/v84-056.

Lindner E. 2003. Use of vegetation types by Svalbard reindeer from Arctic winter to spring. Polar Record 39, 245-247, https://doi.org/10.1017/S0032247403213176.

Manojlović N., Vasiljević P., Jusković M. \& Slobodan S.N. 2010. HPLC analysis and cytotoxic potential of extracts 
from the lichen, Thamnolia vermicularis var. subuliformis. Journal of Medicinal Plants Research 4, 817-823, https://doi. org/10.5897/JMPR 10.104.

Nasser J.A., Yaacob W.A., Din L.B., Yamin B.M. \& Latip J. 2009. Isolation of atranorin, bergenin and goniothalamin from Hopea sangal. ARPN Journal of Engineering and Applied Sciences 4, 92-95.

Olech M., Węgrzyn M., Lisowska M., Słaby A. \& Angiel P. 2011. Contemporary changes in vegetation of polar regions. Papers on Global Change IGBP 18, 35-51, https:// doi.org/10.2478/v10190-010-0003-8.

Orange A., James P.W. \& White F.J. 2001. Microchemical methods for the identification of lichens. London: British Lichen Society.

Orpin C.G., Mathiesen S.D., Greenwood Y. \& Blix A.S. 1985. Seasonal changes in the ruminal microflora of the High-Arctic Svalbard reindeer (Rangifer tarandus platyrhynchus). Applied and Environmental Microbiology 50 , 144-151.

Palo R. 1993. Usnic acid, a secondary metabolite of lichens and its effect on in vitro digestibility in reindeer. Rangifer 13, 39-43, https://doi.org/10.7557/2.13.1.1071.

Piska K., Galanty A., Koczurkiewicz P., Żmudzki P., Potaczek J., Podolak I. \& Pękala E. 2018. Usnic acid reactive metabolites formation in human, rat, and mice microsomes. Implication for hepatotoxicity. Food and Chemical Toxicology 120, 112-118, https://doi.org/10.1016/j.fct.2018.07.005.

Podterob A.P. 2008. Chemical composition of lichens and their medicinal applications. Pharmaceutical Chemistry Journal 42, 582-588, https://doi.org/10.1007/s1 1094-009-0183-5.

Pope P.B., Mackenzie A.K., Gregor I., Smith W., Sundset M.A., McHardy A.C., Morrison M. \& Eijsink V.G.H. 2012. Metagenomics of the Svalbard reindeer rumen microbiome reveals abundance of polysaccharide utilization loci. PLoS One 7, e38571, https://doi.org/10.1371/journal. pone.0038571.

Ragasa C.Y., Tan M.C.S., Alba L.D. \& Shen C.C. A depside from Frullania trichodes Mitt. 2016. Der Pharmacia Lettre 8, 76-78.

Reimers E. 1982. Winter mortality and population trends of reindeer on Svalbard, Norway. Arctic, Antarctic, and Alpine Research 14, 295-300, https://doi.org/10.2307/1550792.

Reimers E. 2012. Svalbard reindeer population size and trends in four sub-areas of Edgeøya. Polar Research 31, article no. 11089, https://doi.org/10.3402/polar.v31i0.1 1089.

Salgado-Flores A., Hagen L.H., Ishaq S.L., Zamanzadeh M., Wright A.D.G., Pope P.B. \& Sundset M.A. 2016. Rumen and cecum microbiomes in reindeer (Rangifer tarandus tarandus) are changed in response to a lichen diet and may affect enteric methane emissions. PLoS One 11, e0155213, https://doi.org/10.1371/journal.pone.0155213.

Shoji J. 1962. Decomposition of usnic acid. VII. Pyrolysis of dihydrousnic acid. (3) Isodihydrousnic acid. Chemical and Pharmaceutical Bulletin 10, 483-491, https://doi. org/10.1248/cpb.10.483.

Smith C.W., Aptroot A., Coppins R.J., Fletcher A., Gilbert O.L., James P.W. \& Wolseley P.A. 2009. Lichens of Great Britain and Ireland. London: British Lichen Society.
Solberg E.J., Jordhøy P., Strand O., Aanes R., Loison A., Sæther B.-E. \& Linnell J.D.C. 2001. Effects of density -dependence and climate on the dynamics of a Svalbard reindeer population. Ecography 24, 441-451, https://doi. org/10.1034/j.1600-0587.2001.d01-200.x.

Sørmo W., Haga Ø.E., Gaare E., Lagvatn R. \& Mathiesen S.D. 1999. Forage chemistry and fermentation chambers in Svalbard reindeer (Rangifer tarandus platyrhynchus). Journal of Zoology London 247, 247-256, https://doi.org/10.1017/ S0952836999002125.

Staaland H., Scheie J.O., Grøndahl F.A., Persen E., Leifseth A.B. \& Holand Ø. 1993. The introduction of reindeer to Brøggerhalvøya, Svalbard: grazing preference and effect on vegetation. Rangifer 13, 15-19, https://doi. org/10.7557/2.13.1.1067.

Stark J.B., Walter E.D. \& Owens H.S. 1950. Method of isolation of usnic acid from Ramalina reticulate. Journal of the American Chemical Society 72, 1819-1820, https://doi. org/10.1021/ja01160a118.

Storeheier P., Mathiesen S., Tyler N. \& Olsen M. 2002. Nutritive value of terricolous lichens for reindeer in winter. Lichenologist 34, 247-257, https://doi.org/10.1006/ lich.2002.0394.

Studzinska-Sroka E., Galanty A. \& Bylka W. 2017. Atranorin-an interesting lichen secondary metabolite. Mini Reviews in Medicinal Chemistry 17, 1633-1645, https:// doi.org/10.2174/1389557517666170425105727.

Sundset M.A., Barboza P.S., Green T.K., Folkow L.P., Blix A.S. \& Mathiesen S.D. 2010. Microbial degradation of usnic acid in the reindeer rumen. Naturwissenschaften 97, 273-278, https://doi.org/10.1007/s001 14-009-0639-1.

Sundset M.A., Edwards J.E., Chen Y.F., Sensiain R.S., Fraile M.N., Northwood K.S., Præsteng, K.E., Glad T.G., Mathiesen S.D. \& Wright A.D.G. 2009. Rumen microbial diversity in Svalbard reindeer, with particular emphasis on methanogenic archaea. Microbial Ecology 70, 553-562, https://doi.org/10.1111/j.1574-6941.2009.00750.x.

Sundset M.A., Kohn A., Mathiesen S.D. \& Præsteng K.E. 2008. Eubacterium rangiferina, a novel usnic acidresistant bacterium from the reindeer rumen. Naturwissenschaften 95, 741-749, https://doi.org/10.1007/ s00114-008-0381-0.

Sundset M.A., Præsteng K.E., Cann I.K., Mathiesen S.D. \& Mackie R.I. 2007. Novel rumen bacterial diversity in two geographically separated sub-species of reindeer. Microbial Ecology 54, 424-438, https://doi.org/10.1007/ s00248-007-9254-x.

Sundset M.A., Salgado-Flores A., Wright A.D.G. \& Pope P.B. 2015. The reindeer rumen microbiome. In K.E. Nelson (ed.): Encyclopedia of metagenomics. Pp. 722-731. Dordrecht: Springer.

Svihus B. \& Holand Ø. 2000. Lichen polysaccharides and their relation to reindeer/caribou nutrition. Journal of Range Management 53, 642-648, https://doi.org/10.2307/4003160.

Tyler N.J.C. 1986. The relationship between the fat content of Svalbard reindeer in autumn and their death from starvation in winter. Rangifer, Special Issue 1, 311-314, https:// doi.org/10.7557/2.6.2.664. 
Van der Knaap W.O. 1986. On the presence of reindeer (Rangifer tarandus L.) on Edgeøya, Spitzbergen in the period 38005000 BP. Circumpolar Journal 2, 3-10.

Wang X.N., Yu W.T. \& Lou H.X. 2005. Antifungal constituents from the Chinese moss Homalia trichomanoides. Chemistry $\theta$ Biodiversity 2, 139-145, https://doi.org/10.1002/cbdv.200490165.

Wegener C., Hansen M. \& Jacobsen L.B. 1992. Effekter av reinbeite ved Kongsfjorden, Svalbard, 1992. Vegetasjonsovervåkning på Svalbard 1991. (Effects of reindeer grazing at Kongsfjorden, Svalbard, Kongsfjorden, Svalbard. Vegetation monitoring in Svalbard 1991.) Norsk Polarinstitutt Meddelelser 121. Oslo: Norwegian Polar Institute.

Wegener C. \& Odasz-Albrigtsen A.M. 1998. Do Svalbard reindeer regulate standing crop in the absence of predators? A test of the "exploitation ecosystems" model. Oecologia 116, 202-206, https://doi.org/10.1007/s004420050580.

Węgrzyn M., Lisowska M. \& Nicia P. 2013. The value of the terricolous Cetrariella delisei in the biomonitoring of heavymetal levels in Svalbard. Polish Polar Research 34, 87-99, https://doi.org/10.2478/popore-2013-0022.
Węgrzyn M. \& Wietrzyk P. 2015. Phytosociology of snowbed and exposed ridge vegetation of Svalbard. Polar Biology 38, 1905-1917, https://doi.org/10.1007/ s00300-015-1751-7.

Węgrzyn M., Wietrzyk P., Lisowska M., Klimek B. \& Nicia P. 2016. What influences heavy metals accumulation in Arctic lichen Cetrariella delisei in Svalbard? Polar Science 10, 532-540, https://doi.org/10.1016/j.polar. 2016.10 .002$.

White P.A.S., Oliveira R.C.M., Oliveira A.P., Seafini M.R., Araújo A.A.S., Gelain D.P., Moreira J.C.F., Almeida J.R.G.S., Quintans J.S.S., Quintans-Junior L.J. \& Santos M.R.V. 2014. Antioxidant activity and mechanisms of action of natural compounds isolated from lichens: a systematic review. Molecules 19, 14496-14527, https://doi. org/10.3390/molecules190914496.

Ziaja W., Dudek J., Ostafin K., Węgrzyn M., Lisowska M., Olech M. \& Osyczka P. 2016 Transformation of the natural environment in western Sørkapp Land (Spitsbergen) since the 1980s. Dordrecht: Springer. 